\title{
Populational Affinities of the Peruvian with Siberians and North Americans: A Nonmetric Cranial Approach.
}

\author{
HAJIME ISHIDA \\ Department of Anatomy, Sapporo Medical College, \\ S-1, W-17, Chuo-ku, Sapporo 060, Japan
}

Received June 8, 1992

\begin{abstract}
Nonmetric traits of Peruvian skulls were examined for evidence bearing on their populational affinities. Significant frequency differences from the Peruvian gradually increased in number with geographic distance, and clines were seen in the frequency patterns of several traits of cranial series compared. Distance analyses based on the MMDs revealed that the Peruvian and Ontario Iroquois formed an intimate cluster, which shows a closer affinity with the Arctic peoples, especially the Aleut, than with other Siberians. As a result, we can conclude that the American Indians are derived from the North Asian populations including the Arctic peoples, though their exact origins remain unclear.
\end{abstract}

Key Words: Peruvians, American Indians, Siberians, nonmetric cranial variation, Mongoloid

\section{INTRODUCTION}

It is generally accepted that peoples who had originated in Asia were formerly distributed throughout vast areas of Siberia and the Far East, and then some of their descendants dispersed into the Americas via the now submerged Bering Land Bridge (Beringia). Because American anthropologists including Ales Hrdlicka have always been concerned about the peopling of the Americas, many ideas have been offered on the time and routes as well as the original tribes and numbers of the migration to the New World (see Harper and Laughlin, 1982). Hrdlicka (1942), after his investigation in the former Soviet Union in 1939, made a systematic report on human skeletal remains from Siberia. He claimed these to be key evidence of AsianAmerican connections. Those collections, however, have been mainly investigated not by American or other western anthropologists, but by Russians (e.g., Trofimova, 1932; Debets, 1951; Levin, 1963; Alekseev, 1979).

Historically, most reports on paleolithic and neolithic human skeletal remains from Siberia have been published in Russian, by Russian anthropologists (Alekseev and Gochman, 1983, 1987; Balueva, 1978; Debets, 1951; Levin, 1963). Trubnikova analyzed cranial metric data of the Siberian, East Asian and American populations to analyze affinities between them (Trubnikova, 1980; Alekseev and Trubnikova, 1984). In addition, some Russian anthropologists have tried to elucidate the 
populational relationships between the Siberian and other circum-Pacific peoples through the analysis of nonmetric cranial traits (Rychikov and Movsesyan, 1972; Kozintsev, 1980, 1988a, 1988b, 1990; Tomashevich, 1988).

Turning to efforts by others, a joint USA-USSR field research team excavated human skeletal remains at prehistoric burial sites near Lake Baikal in 1975 (Laughlin et al., 1976). The dental morphology and nonmetric cranial traits of the Siberians have been the subjects of numerous recent investigations, resulting in various hypotheses on prehistoric Mongoloid dispersal (Turner, 1971, 1983, 1985, 1986a, 1986b, 1987, 1989, 1990; Turner and Bird, 1981; Greenberg et al., 1986; Ossenberg, 1986, 1992). Yamaguchi $(1977,1981)$ of Japan compared skeletal samples of the Ontario Iroquois with those of East Asians.

In 1988-1989, and 1991, the author had the opportunity to investigate the cranial metric and nonmetric characters of the Siberian populations in collections in the former Soviet Union. Some results of the analysis on facial flatness and nonmetric traits have been reported in previous papers (Ishida, 1990, 1992, 1993; Ishida and Dodo, 1990a, 1992; Ishida and Kida, 1991). In 1991, the author had the opportunity to examine cranial metric and nonmetric characters of the Peruvian skeletal collection in the USA. The purposes of this study are to present the nonmetric cranial traits of the Peruvian series and to measure populational affinities between the Siberians and Americans in terms of nonmetric cranial traits.

\section{MATERIAL AND METHODS}

The Peruvian cranial samples used are housed in the National Museum of Natural History, Washington, D.C., U.S.A. The crania of 84 males and 84 females from Chicama were examined in this study. Although Ossenberg (1970) indicated that artificial cranial deformation influences the occurrence of some nonmetric cranial variants, only severely deformed crania of the Peruvian samples were excluded for the nonmetric investigation. The skulls were examined for the presence or absence of thirty-three nonmetric cranial traits, as defined by Dodo $(1972,1974,1986 a)$ and Ossenberg (1969).

The comparison samples collected by the present author are the Aleut, Asian Eskimo, Ekven (the Iron Age), Buryat, Neolithic Baikal, Mongolian, Tagar (the Iron age, southern Siberia), Kazach, Hokkaido Ainu (Ishida and Dodo, 1992), Amur (Ishida, 1990) and Sakhalin Ainu (Ishida and Kida, 1991). In addition, samples of Asian and North American peoples gathered by Dodo were used for comparison: Modern Japanese, Mongolian, Alaskan Eskimo, Canadian Eskimo, Aleut, Ontario Iroquois (Dodo and Ishida, 1987), Jomon, Aeneolithic Doigahama Yayoi, Protohistoric Kofun (Dodo and Ishida, 1990), Northern Chinese (Dodo et al., 1992), Hawaiian and Chamorro (Ishida and Dodo, 1993).

The biological distances between the Peruvian series and five other populations 
were estimated by mean measure of divergence (MMD) and its standard deviation based on the incidences per individual of 22 nonmetric traits (Søvold, 1973). Because we had selected 16 of those traits as having high interobserver consistency (Ishida and Dodo, 1990b, 1992), these 16 traits were employed for wider comparisons including the Asian and North American samples examined by Dodo. Clustering (group average method) and principal coordinate analyses were applied to the distance matrices of the MMDs to establish two or three dimensional relationships (Sneath and Sokal, 1973).

\section{RESULTS}

The Table in the Appendix summarizes the numbers examined and incidences per individual in the Peruvian sample. The high incidence of the supraorbital foramen in the Peruvians matched that of the Asian and North American samples, whereas the low frequency of transverse zygomatic-suture vestige is comparable only to the North American series reported by Dodo and Ishida (1987). The Peruvians have some high incidences of bridging or hyperostotic traits such as hypoglossal canal bridging, clinoid bridging, mylohyoid bridging and aural exostosis; they also often show tympanic dehiscence, which has been classified as a hypostotic variation by Ossenberg (1969). Fifteen crania have both tympanic dehiscence and aural exostosis.

The incidences of 22 nonmetric cranial traits in the Peruvian sample were compared with those of five ethnic groups: the Aleut, Asian Eskimo, Amur, Mongolian, and Hokkaido Ainu, all the data of which were collected by the author (Table 1). Five traits in the Aleut, nine in the Asian Eskimo, 12 in the Amur, nine in the Mongolian, and 11 in the Hokkaido Ainu were significantly different from the Peruvian sample.

Dodo and Ishida (1990) have selected the following five nonmetric traits as the most efficacious for distinguishing between the populations in question: the supraorbital foramen, hypoglossal canal bridging, medial palatine canal, transverse zygomatic-suture vestige and mylohyoid bridging. These are graphically compared between the six samples (Fig. 1). The frequency of the supraorbital foramen in the Hokkaido Ainu (0.283) is considerably lower than in the other five samples; conversely, the frequency of transverse zygomatic-suture vestige is higher. As for hypoglossal canal bridging and mylohyoid bridging, the Amur and Mongolian, have lower incidences than the Hokkaido Ainu and the two Arctic and Peruvian samples. On the other hand, the frequency of the transverse zygomatic-suture vestige is low in the Asian Eskimo and Peruvian series. The frequency patterns of the five traits suggest that the six ethnic samples are divided into the following three groups: the Hokkaido Ainu, the Amur and Mongolian, and the two Arctic and Peruvian populations. 


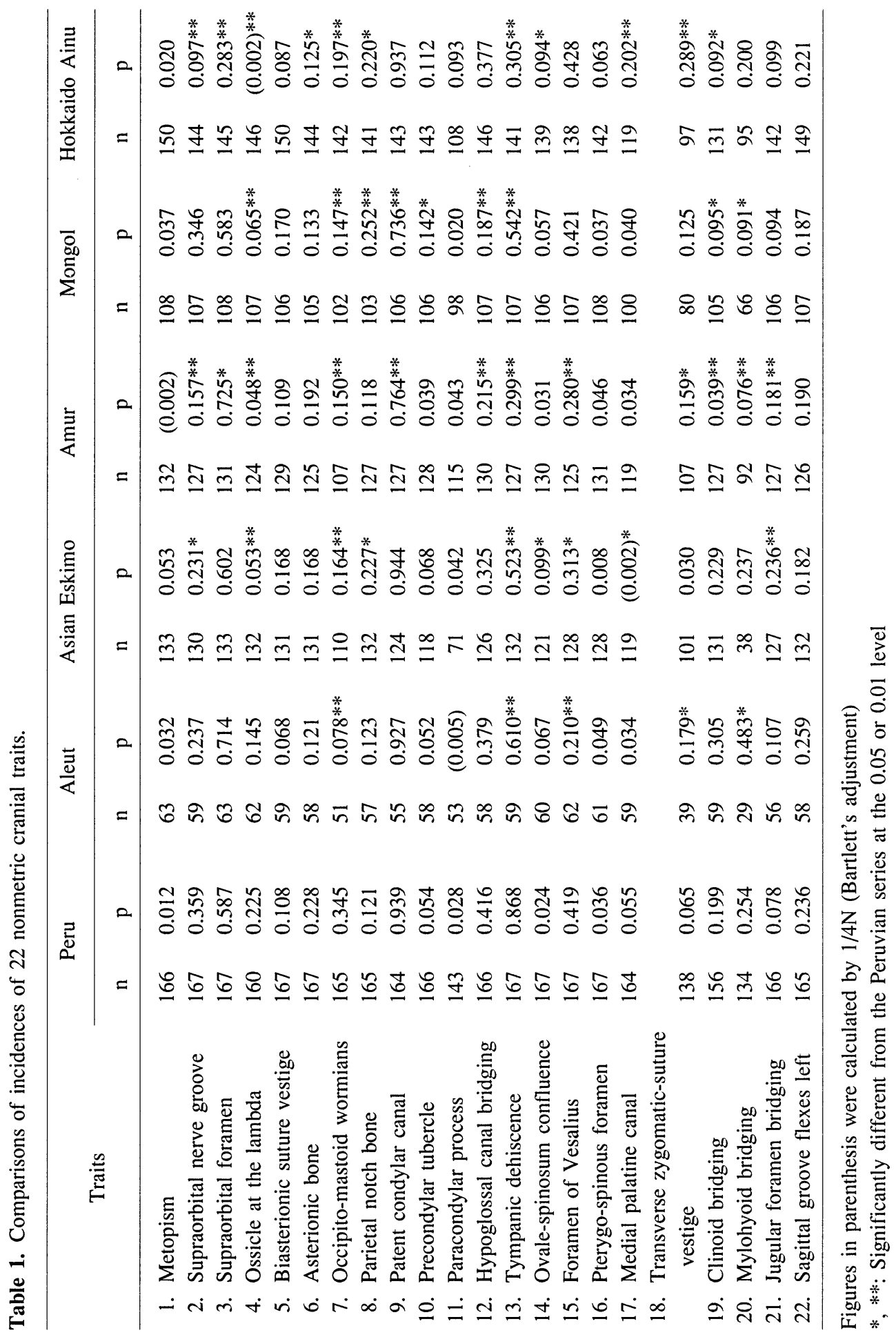




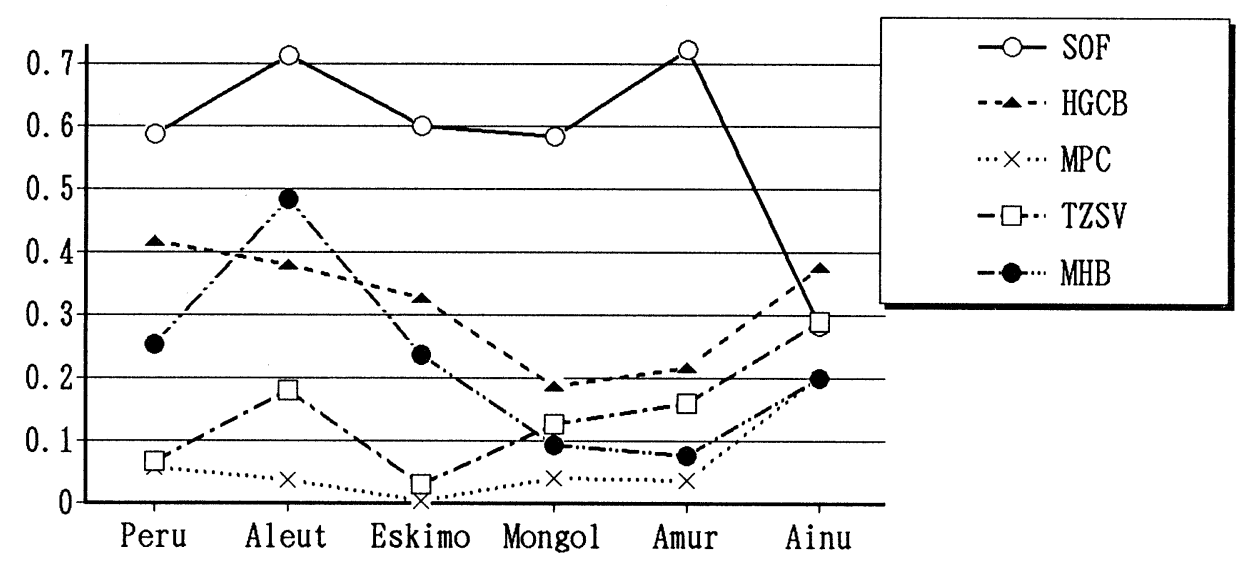

Fig. 1. Frequencies of the five most distinguishing nonmetric cranial traits by Dodo and Ishida (1990). SOF, supraorbital foramen; HGCB, hypoglossal canal bridging; MPC, medial palatine canal; TZSV, transverse zygomatic-suture vestige; MHB, mylohyoid bridging.

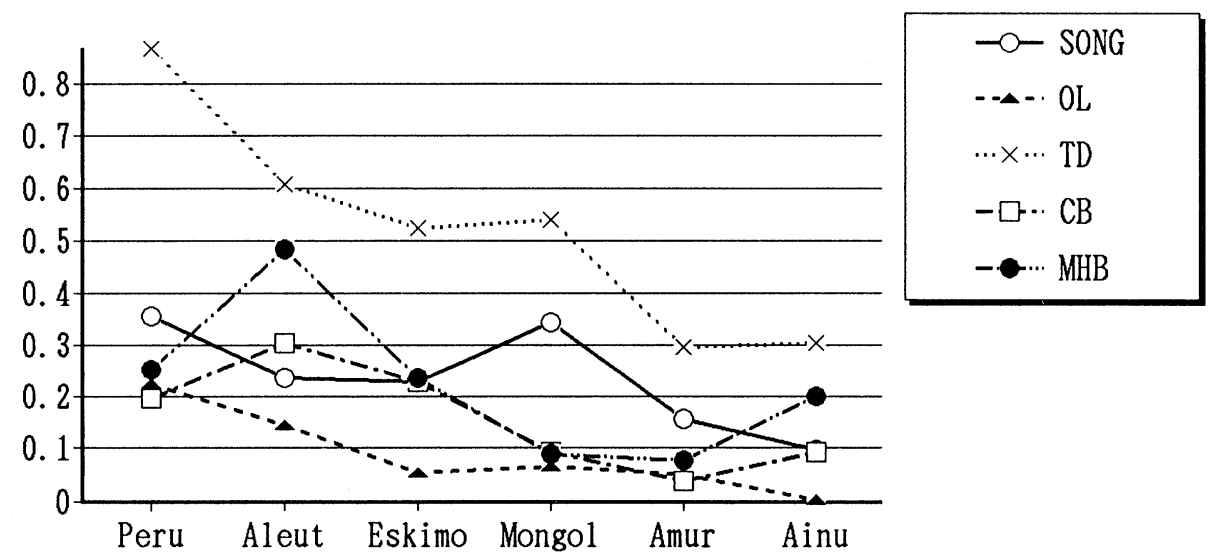

Fig. 2. Frequencies of the five nonmetric cranial traits, showing gradual changes, or clines from Asia to America. SONG, supraorbital nerve groove; OL, ossicle at the lambda; TD, tympanic dehiscence; $\mathrm{CB}$, clinoid bridging; MHB, mylohyoid bridging. 
It is found that the frequencies of the following five traits tend to show clines from Asia to the Americas: the supraorbital nerve groove, the ossicle at the lambda, tympanic dehiscence, clinoid bridging and mylohyoid bridging, as drawn in Fig. 2. In order to confirm that the gradual change in populational affinity from Asia to America actually exists, Smith's MMDs and their standard deviations for the six populations were calculated from the incidence data of the 22 traits, listed in Table 1. The MMD matrix is shown in Table 2. All the MMDs between the six samples are significant. The closest to the Peruvians are the Aleut, with next closest being the Asian Eskimo, while the Amur and Hokkaido Ainu are at a good distance to the Peruvians. The Aleut and Asian Eskimo are closer to the Mongolian than to the Amur peoples; this differs from one of this writer's previous results (Ishida and Kida, 1991).

Table 2. Matrix of the MMDs and their standard deviations based on the 22 nonmetric traits.

\begin{tabular}{lccccc}
\hline & 1 & 2 & 3 & 4 & 5 \\
\hline 1. Peru & - & & & & \\
2. Aleut & 0.0616 & - & & & \\
& $(0.0075)$ & & & & \\
3. Asian & 0.0747 & 0.0413 & - & & \\
$\quad$ Eskimo & $(0.0048)$ & $(0.0086)$ & & & \\
4. Amur & 0.1529 & 0.1036 & 0.0730 & - & - \\
& $(0.0043)$ & $(0.0081)$ & $(0.0054)$ & & \\
5. Mongol & 0.0887 & 0.0854 & 0.0466 & 0.0371 & \\
& $(0.0049)$ & $(0.0087)$ & $(0.0059)$ & $(0.0055)$ & \\
6. Hokkaido & 0.1843 & 0.1378 & 0.1152 & 0.0983 & 0.0965 \\
$\quad$ Ainu & $(0.0042)$ & $(0.0079)$ & $(0.0052)$ & $(0.0047)$ & $(0.0053)$ \\
\hline
\end{tabular}

Principal coordinate analysis was applied to the MMD matrix of Table 2 to establish two dimensional relationships (Fig. 3). The Peruvian, Aleut, Asian Eskimo, Mongolian and Amur are situated in a line, basically corresponding to their geographic relationships. The isolated position of the Hokkaido Ainu is clearly recognized.

Smith's MMDs and their standard deviations were computed for the 22 circumPacific populations, based on the incidence data of the 16 nonmetric traits. Clustering analysis by the group average method was applied to the MMD matrix of the 22 populations, as shown in Fig. 4. The Jomon and Hokkaido Ainu do not show affinities with the other populations, thus forming an isolated cluster. The Asian, Siberian and American populations are in a large cluster within which three 


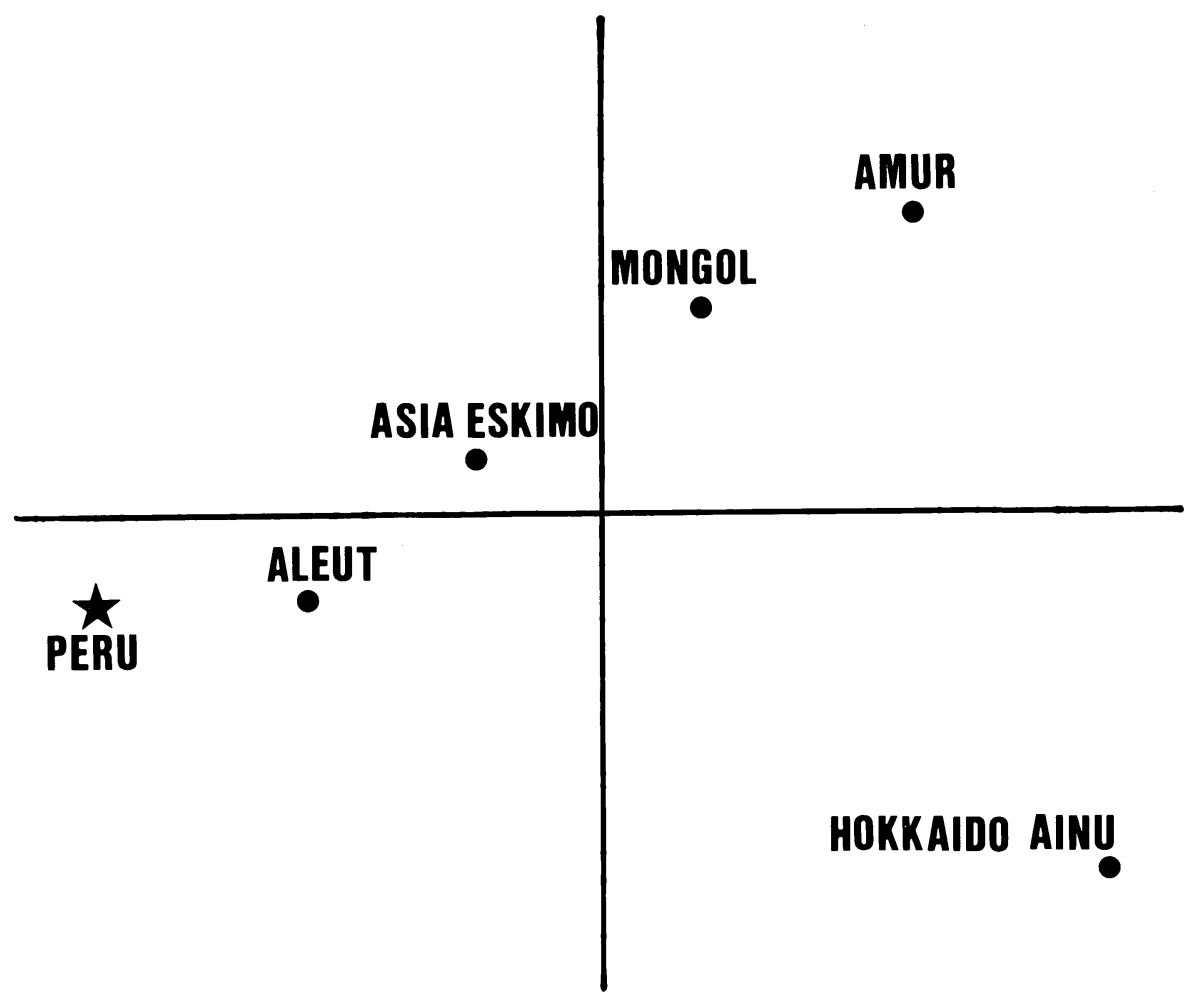

Fig. 3. Two-dimensional representation of six population samples by principal coordinate analysis applied to the MMD matrix of Table 2.

groups are identifiable. The first group is divided into two subgroups: one contains the American Indians and Tagar from Siberia; the Arctic populations in Siberia and North America are in the other subgroup. The Chamorro and Hawaiian from the Pacific are loosely lumped with each other to make the second cluster. The third group contains two subgroups: one consists of the Neolithic Baikalian, Amur and Sakhalin Ainu; the Northern Chinese, Mongolian, Kazach, Buryat, and three Japanese populations join to make the other subgroup.

Principal coordinate analysis was also applied to the MMD matrix of the 22 populations. The result, drawn in Fig. 5, is almost the same as that of the clustering analysis. The indigenous American and Arctic populations are loosely joined to make a cluster, where the Peruvian is closer to the Arctic groups than the Ontario Iroquois. The Siberians classified as the Central Asiatic type by Debets (1951), Kazach, East Asians, and the three Japanese are in another loose cluster, to which the Tagar stand somewhat near. The Amur, although being more distant from the 
Americans than the Mongolian in Fig. 3, are situated intermediately between the East Asian and Central Asiatic type Siberians, and the Arctic and indigenous Americans in this figure. While the Jomon and Hokkaido Ainu cluster is isolated from the others, the Sakhalin Ainu and Neolithic Baikalian are located around the center of the populations compared.

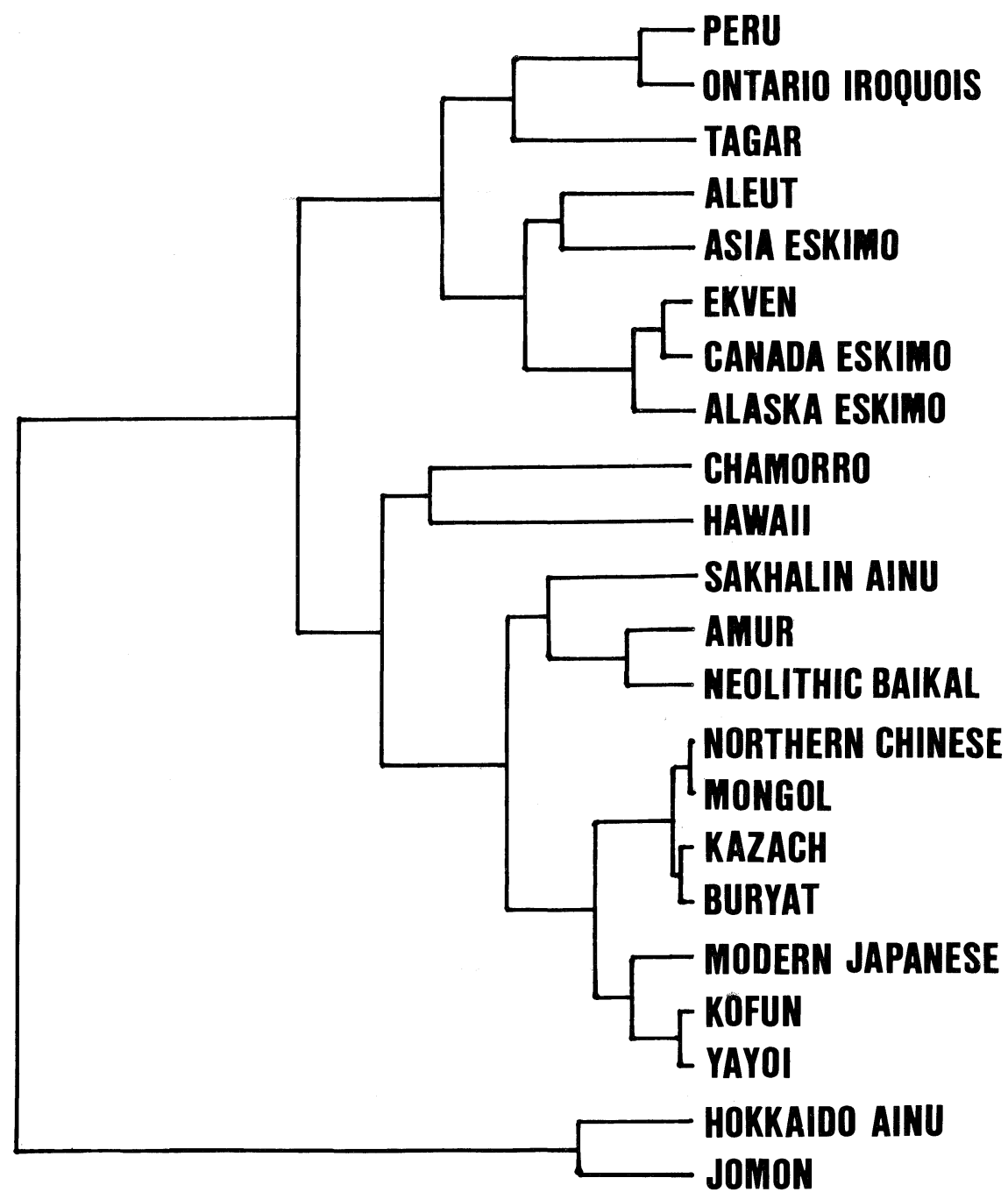

Fig. 4. Cluster analysis (group average method) applied to the MMD matrix of 22 circum-Pacific populations. 


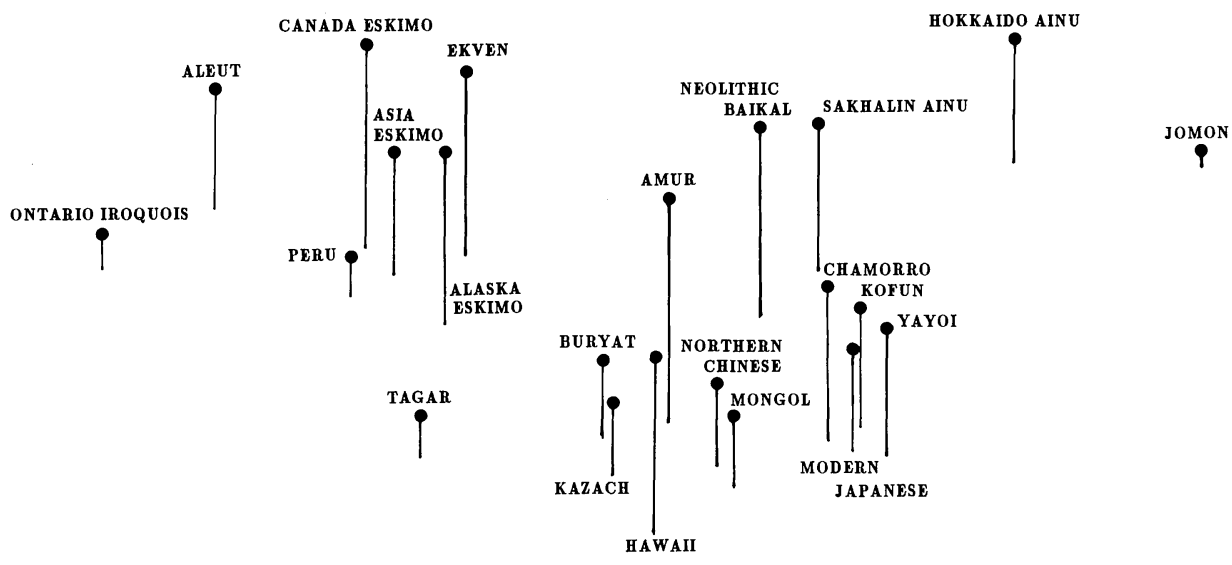

Fig. 5. Three-dimensional representation of 22 population samples by principal coordinate analysis applied to the MMD matrix.

\section{DISCUSSION}

The nonmetric characteristics of the Peruvians examined have much in common with other American Indians in that high frequencies of the supraorbital foramen, ossicle at the lambda, hypoglossal canal bridging, clinoid bridging and mylohyoid bridging, and low incidence of the transverse zygomatic-suture vestige are also recognized in the cranial series of the Brazil Indian (Alvim and Soares, 1981), Ontario Iroquois (Dodo and Ishida, 1987) and North American Indians (Ossenberg, 1992). Ossenberg (1970) examined nonmetric cranial traits in fronto-occipitally deformed crania and indicated that the frequency of tympanic dehiscence decreases in the deformed crania. However, the Peruvian samples, consisting of some moderately or slightly fronto-occipitally deformed crania, have the highest incidence of tympanic dehiscence of all populations compared. It seems that artificial cranial deformation had little effect on the incidence pattern of nonmetric traits in the Peruvian case. Further, cranial deformation may have little impact on the calculation of biological distances between populations based on nonmetric traits, though some types of deformation could affect frequencies of a few nonmetric traits (Konigsberg et al., 1993).

In the analysis of six populations, it was again demonstrated that the indigenous Americans originated from Asia, because gradual changes or clines are recognized both in the numbers of significant frequency differences from the Peruvians and in the frequency patterns of several traits. Moreover, the principal coordinate analysis, based on the MMDs, shows that five of these six populations are arranged linearly 
corresponding to their geographic distribution (Fig. 3). The Hokkaido Ainu, however, show different frequency patterns of nonmetric traits, as drawn in Fig. 1, and stands out at a good distance from the other five populations in Fig. 3. Those two groupings of the Ainu and the other five populations, which were already indicated by craniometric analysis (Yamaguchi, 1982), coincide with sundadonty and sinodonty of Turner (1990), respectively. The Peruvians are closer to the Aleut than to the Eskimo, which corresponds to the result of Ossenberg (1992).

The 22 populations from the East Asia, Siberia and America were clearly classified into several clusters through the clustering and principal coordinate analyses.

\section{Jomon, Ainu, and the Pacific Peoples}

The Jomon and Hokkaido Ainu are near each other and make an isolated cluster. Their close relationship has been indicated by analyses of craniometry, nonmetric cranial trait and dental morphology (e.g., Yamaguchi, 1982; Ossenberg, 1986; Dodo, 1986b; Turner, 1976), including some by this author (Ishida, 1990, 1992; Ishida and Kida, 1991; Ishida and Dodo, 1992). Their isolated position is seen in the nonmetric analysis. (According to Ossenberg (1986), Jomon and Ainu are "insular.") Craniometry also indicated that the series of the classic Mongoloids are generally distant from the Jomon series (Trubnikova, 1980; Yamaguchi, 1982). The Jomon and Ainu are classified as a sundadont group together with Southeast Asian peoples in dental morphology (Turner, 1990). Moreover, Brace claims through an analysis of tooth size and cranial measurements, of which two thirds relate to the nasal skeleton, that there is a close relationship between the Jomon-Ainu and the Pacific peoples which he calls "the Jomon-Pacific cluster" (Brace and Hunt, 1990; Brace et al., 1990). This cluster has not been recognized by our nonmetric analysis, so we have not supported that view in previous studies (Ishida and Dodo, 1993; Ishida, 1993). Hanihara (1992) has also denied a direct relationship between the Jomon and the Pacific populations on the basis of dental morphology.

Turner's hypothesis that the Jomon and Ainu are the northernmost distribution of sundadont has been supported by dental and cranial morphology (Hanihara, 1989, 1990, 1991). Based on the nonmetric cranial analysis by Ossenberg (1992), the Jomon and Ainu are positioned within the Mongoloid cluster. Because no cranial series from mainland and island Southeast Asia were included here, we are not able to judge whether they show close affinities with the Jomon and Ainu or not. However, it can be said that the results of the nonmetric cranial study presented here, which includes the Pacific peoples, contradict the results of the dental study by Turner. 


\section{East Asians and Siberians}

According to Debets (1951), on the basis of somatology and craniology, the eastern Siberian Mongoloids are divided into three major groups: the Arctic, Baikal and Central Asiatic types. That grouping, generally accepted by Russian anthropologists (Alekseev and Gochman, 1983), was also confirmed by studies of nonmetric cranial traits (Ishida and Dodo, 1992) and facial flatness (Alekseev, 1979; Ishida, 1992). The Central Asiatic peoples, consisting of the Buryat, Mongolian and southern Siberians, are close not only to the Northern Chinese and other East Asians but also to the Kazach. They seem to have been genetically influenced by people from China during the Iron and middle Ages. Many anthropological researches have shown that the European peoples inhabited western Siberia and western Mongolia during the neolithic and Bronze Ages, and that the Asian peoples dispersed there later (e.g., Alekseev, et. al., 1987; Han, 1986); furthermore, the Central Asiatic peoples and Kazach have an affinity with the Northern Chinese, as shown by another nonmetric study and HLA analysis (Ishida and Dodo, 1992; Saitou et al., 1992).

The peoples of the Baikal type consist of the Evenki, Yukagir, and several ethnic groups in the Amur basin, with which the Neolithic Baikalian shows a close affinity in the craniological analyses of the Russians (Alekseev, 1979; Alekseev and Gochman, 1983) and ours (Ishida and Dodo, 1992; Ishida, 1993). Turner (1987), in contrast, mentioned that the Neolithic Baikalian and the peoples of North China and Mongol are lumped to make a cluster. The grouping of the Siberian and East Asian peoples may have reflected their local microevolutions, though cranial morphology and dental traits seem to contradict each other here.

The Arctic type peoples in Siberia are surely close to the Arctic Americans as both of them have the following peculiar physical characteristics: high value of the mandibular ramus index, high occurrences of the mandibular torus and three rooted first lower molar, and pronounced nasal bones (Turner, 1971; Laughlin et al., 1979; Dodo and Ishida, 1987; Ishida, 1992). Their physical characteristics can be traced back to the skull from the Ust'-Belsk cemetery in the Bronze Age (Gochman, 1961).

\section{Indigenous Americans}

The Peruvian samples examined in this study proved to show common features of the American Indians and made a cluster with the Ontario Iroquois by the clustering analysis, drawn in Fig. 4. That reconfirmed the physical homogeneity within the American Indian groups, which has been observed for dental morphology, craniometry and genetics (Turner, 1983, 1985, 1986b; Howells, 1989; CavalliSforza et al., 1988). Based on their low dental variation, Turner (1985) has indicated that most Indians originated from a single, relatively small population that entered late into the New World.

As a result of craniological and osteological analyses (Yamaguchi, 1977, 1981; 
Laughlin et al., 1979; Brace and Hunt, 1990), it was thought, historically, that the American Indians were isolated and showed considerable differences in morphology not only from the northeast Asians but also from the Eskimo and Aleut. Alekseev (1979), however, maintained that the Arctic peoples resemble the North Americans more closely than other Siberians.

Several craniometric studies have indicated an affinity of the American Indians not with the Northeast Asians, but with the Europeans (Howells, 1989; Ishida, 1992) or with the Jomon-Pacific cluster (Li et al., 1991); this, however, has not been detected in other anthropological studies. Many anthropological studies, including craniometry, nonmetric cranial variants, dental morphology and genetics, have indicated that the American Indians are generally closer to the northeastern Asians than to the Southeast Asians or to the Europeans which coincides with my results in this study. However, various more detailed proposals for their exact origin have been offered. For example, the American Indians show a close affinity with the following ethnic groups: the Arctic peoples by nonmetric cranial variants (Ossenberg, 1992) and craniometry (Trubnikova, 1980), the East Asian by craniometry (Alekseev and Trubnikova, 1984), the Buryat by craniometry (Howells, 1989), the people in the Upper Lena by dental morphology (Turner, 1983, 1985, 1986b).

Turner $(1985,1986 \mathrm{~b})$ has denied the view that the American Indian teeth have a slight influence from the European peoples, which he once offered (Turner, 1983). He considered, although showing no concrete material, that ancestors of the PaleoIndians, after separating from the North China populations, inhabited the Upper Lena River basin. Craniometrical analyses have provided conflicting conclusions on the native place of Paleo-Indians. This nonmetric study also did not find the direct ancestors of the American Indians within the Siberian and East Asian populations. However, we can only postulate that the Arctic peoples, although differing from the American Indians in some respects, are most similar to the American Indians in nonmetric cranial variations, as mentioned by Ossenberg (1992).

\section{ACKNOWLEDGEMENTS}

For their permission to study cranial materials I wish to thank the following: Drs. D.H. Ubelaker, D.R. Hunt, National Museum of Natural History, Washington, D.C.; Drs. I.I. Gochman, A.G. Kozintsev, the Institute of Ethnography-St. Petersburg Branch, St. Petersburg; Drs. A.P. Derevyanko, T.A. Chikisheva, the Institute of Ethnography and Archaeology, Novosibirsk; the late Academician V.P. Alekseev, the Institute of Archaeology, Moscow; Dr. T.I. Alekseeva, the Moscow State University, Moscow; Drs. W.D. Duckworth, Y.H. Sinoto, B.P. Bishop Museum, Honolulu; Drs. B. Endo, T. Akazawa, University of Tokyo; Drs. H. Ishida, K. Katayama, Kyoto University.

This study was supported in part by Grant-in-aid for International Scientific 
Research and for Scientific Research on Priority Areas from the Ministry of Education, Science and Culture, Japan (No. 01643506, 02225208, 03209206 and 04208206), a Fellowship for Research in the Soviet Union from the Japan Society for the Promotion of Science and a Research Fellowship from the Sapporo Medical College.

Appendix Table. Incidences per capita of 33 nonmetric cranial variants in the Peruvian series.

\begin{tabular}{lcc}
\hline \multicolumn{1}{c}{ Traits } & number & incidence \\
\hline 1. Metopism & 166 & 0.012 \\
2. Supraorbital nerve groove & 167 & 0.359 \\
3. Supraorbital foramen & 167 & 0.587 \\
4. Foramen meningo-orbitale & 164 & 0.610 \\
5. Infraorbital suture & 165 & 0.794 \\
6. Accessory infraorbital foramen & 165 & 0.176 \\
7. Ossicle at the lambda & 160 & 0.225 \\
8. Interparietals & 167 & 0.030 \\
9. Biasterionic suture & 167 & 0.108 \\
10. Asterionic bone & 167 & 0.228 \\
11. Occipito-mastoid wormians & 165 & 0.345 \\
12. Parietal notch bone & 165 & 0.121 \\
13. Condylar canal patent & 164 & 0.939 \\
14. Third occipital condyle & 166 & 0.036 \\
15. Precondylar tubercle & 166 & 0.054 \\
16. Paracondylar process & 143 & 0.028 \\
17. Hypoglossal canal bridging & 166 & 0.416 \\
18. Tympanic dehiscence & 167 & 0.868 \\
19. Ovale-spinosum confluence & 167 & 0.024 \\
20. Foramen of Vesalius & 167 & 0.419 \\
21. Pterygo-spinous foramen & 167 & 0.036 \\
22. Pterygo-alar bridging & 167 & 0.036 \\
23. Medial palatine canal & 164 & 0.055 \\
24. Aural exostosis & 168 & 0.131 \\
25. Transverse zygomatic-suture vestige & 138 & 0.065 \\
26. Clinoid bridging & 156 & 0.199 \\
27. Accessory mental foramen & 134 & 0.134 \\
28. Mylohyoid bridging & 134 & 0.254 \\
29. Mandibular torus & 134 & 0.007 \\
30. Jugular foramen bridging & 166 & 0.078 \\
31. Intermediate condylar canal & 160 & 0.506 \\
32. Sagittal groove flexes left & 165 & 0.236 \\
33. Palatine torus & 167 & 0.000 \\
\hline & & \\
\hline & & \\
\hline
\end{tabular}




\section{REFERENCES}

Alekseev, V.P. (1979) Anthropometry of Siberian peoples. In The First Americans: Origins, Affinities and Adaptations (Laughlin, W., and Harper, A., ed.), Gustav Fischer, New York, pp. 57-90.

Alekseev, V.P., and Gochman, I.I. (1983) Physical anthropology of Soviet Asia. In Rassengeschichte der Menschheit. 9. Asien II: Sowjet-Asien (Schwidetzky, I., ed.), R. Oldenbourg Verlag, München, pp. 7-166.

Alekseev, V.P., and Gochman, I.I. (1987) Remains of child skeletons from the paleolithic burials at the Malta site. Izvestiya sibirskovo otdeleniya akademii nauk SSSR 3, 53-60. (In Russian)

Alekseev, V.P., Gochman, I.I., and Tumen, D. (1987) A brief report on the paleoanthropology of the central Asia (Stone age - early Iron age). In Archaeology and Anthropology of Mongol, Nauka, Novosibirsk, pp. 208-241. (In Russian)

Alekseev, V.P., and Trubnikova, O.B. (1984) Some Problems of Taxonomy and Genealogy of the Asiatic Mongoloids (Craniometry), Nauka, Novosibirsk. (In Russian)

Alvim, M.C.M. and Soares, M.C. (1981) Incidencia de tracos nao-metricos em material de sambaqui do Acervo do Museu Nacional da Universidade federal do Rio de Janeiro. Dos Arquivos de Anatomia e Antropologia 6, 315-333. (In Portuguese)

Balueva, T.S. (1987) Craniological material of neolithic layer of the cave $<$ Devil's gate $>$ (Primorje). Vopr. Antropol. 58, 184-187. (In Russian with English title)

Brace, C.L., Brace, M.L., Dodo, Y., Hunt, K.D., Leonard, W.R., Li, Y., Sangvichien, S., Xiang-qing, S., and Zhenbiao, Z. (1990) Micronesians, Asians, Thais and relations: A craniofacial and odontometric perspective. Micronesica (Suppl.) 2, 323-348.

Brace, C.L. and Hunt, K.D. (1990) A nonracial craniofacial perspective on human variation: A(ustralia) to Z(uni). Am. J. Phys. Anthropol. 82, 341-360.

Cavalli-Sforza, L.L., Piazza, A., Menozzi, P., and Mountain, J. (1988) Reconstruction of human evolution: Bringing together genetic, archaeölogical, and linguistic data. Proc. Natl. Acad. Sci. USA 85, 6002-6006.

Debets, G.F. (1951) Anthropological studies in the Kamchatka region. Trudy. Inst. Ethnogr. n.s. 17, 1-263. (In Russian)

Dodo, Y. (1972) Aural exostosis in the human skeletal remains excavated in Hokkaido. J. Anthrop. Soc. Nippon 80, 11-22. (In Japanese with English summary)

Dodo, Y. (1974) Non-metrical cranial traits in the Hokkaido Ainu and the northern Japanese of recent times. J. Anthrop. Soc. Nippon 82, 31-51.

Dodo, Y. (1986a) A population study of the jugular foramen bridging of the human cranium. Am. $J$. Phys. Anthropol. 69, 15-19.

Dodo, Y. (1986b) Metrical and non-metrical analyses of Jomon crania from eastern Japan. In Prehistoric Hunter-Gatherers in Japan (Akazawa, T., and Aikens, C.M., ed.), University of Tokyo Press, Tokyo, pp. 137-161.

Dodo, Y., and Ishida, H. (1987) Incidence of nonmetric cranial variants in several population samples from East Asia and North America. J. Anthrop. Soc. Nippon 95, 161-177.

Dodo, Y., and Ishida, H. (1990) Population history of Japan as viewed from cranial nonmetric variation. J. Anthrop. Soc. Nippon 98, 269-287.

Dodo, Y., Ishida, H., and Saitou, N. (1992) Population history of Japan: A cranial nonmetric approach. In The Evolution and Dispersal of Modern Humans in Asia (Akazawa, T., Aoki, K., and Kimura, T., ed.), Hokusen-sha, Tokyo, pp. 479-492.

Gochman, I.I. (1961) An ancient skull from the Chukotka. Report of Chukotka Topographical Museum 2, 14-18. (In Russian) (cited from Alekseev and Gochman, 1983) 
Greenberg, J.H., Turner, C.G., II, and Zegura, S.T. (1986) The settlement of the Americas: A comparison of the linguistic, dental, and genetic evidence. Current Anthropology 27, 477-497.

Han, K. (1986) Anthropological characters of the human crania from Loulan site, Xinjiang. Acta Antropologica Sinica 5, 227-242. (In Chinese with English summary)

Hanihara, T. (1989) Comparative studies of geographically isolated populations in Japan based on dental measurements. J. Anthrop. Soc. Nippon 97, 95-107.

Hanihara, T. (1990) Studies on the affinities of Sakhalin Ainu based on dental characters: The basic populations in East Asia III. J. Anthrop. Soc. Nippon 98, 425-437.

Hanihara, T. (1991) The origin and microevolution of Ainu as viewed from dentition: The basic populations in East Asia VIII. J. Anthrop. Soc. Nippon 99, 345-361.

Hanihara, T. (1992) Biological relationships among Southeast Asians, Jomonese, and the Pacific populations as viewed from dental characters: The basic populations in East Asia X. J. Anthrop. Soc. Nippon 100, 53-67.

Harper, A.B., and Laughlin, W.S. (1982) Inquiries into the peopling of the New World: Development of ideas and recent advances. In A History of American Physical Anthropology 1930-1980 (Spencer, F., ed.), Academic Press, New York, pp. 281-304.

Howells, W.W. (1989) Skull Shapes and the Map. Papers of the Peabody Museum of Archaeology and Ethnology, 79, Harvard University Press, Cambridge.

Hrdlička, A. (1942) Crania of Siberia. Am. J. Phys. Anthropol. 29, 435-481.

Ishida, H. (1990) Cranial morphology of several ethnic groups from the Amur basin and Sakhalin. J. Anthrop. Soc. Nippon 98, 137-148.

Ishida, H. (1992) Flatness of facial skeletons in Siberian and other circum-Pacific populations. $Z$. Morph. Anthrop. 79, 53-67.

Ishida, H. (1993) Cranial nonmetric variation of circum-Pacific populations with special reference to the Pacific peoples. Japan Review (Suppl.), in press.

Ishida, H., and Dodo, Y. (1990a) Flatness of face. J. Soc. Biomechanisms 14, 200-206. (In Japanese)

Ishida, H., and Dodo, Y. (1990b) Interobserver error in scoring nonmetric cranial traits. J. Anthrop. Soc. Nippon 98, 403-409.

Ishida, H., and Dodo, Y. (1992) Differentiation of the northern Mongoloid: The evidence of cranial nonmetric traits. In Japan in the World IV: Japanese as a Member of the Asian and Pacific Populations (Hanihara, K., ed.), International Research Center for Japanese Studies Press, Kyoto, pp. 79-94.

Ishida, H., and Dodo, Y. (1993) Nonmetric cranial variation and the populational affinities of the Pacific peoples. Am. J. Phys. Anthropol. 90, in press.

Ishida, H., and Kida, M. (1991) An anthropological investigation of the Sakhalin Ainu with special reference to nonmetric cranial traits. J. Anthrop. Soc. Nippon 99, 23-32.

Konigsberg, L.W., Kohn, L.A.P., and Cheverud, J.M. (1993) Cranial deformation and nonmetric trait variation. Am. J. Phys. Anthropol. 90, in press.

Kozintsev, A.G. (1980) Discrete traits on the crania of the Bronze Age from the South Siberia. In The Investigations on the Paleoanthropology and Craniology in the USSR (Gochman, I.I., ed.), Bulletin of Museum of the Anthropology and Ethnography, 36, Nauka, Leningrad, pp. 75-99. (In Russian)

Kozintsev, A.G. (1988a) Ethnic Cranioscopy, Nauka, Leningrad. (In Russian with English summary)

Kozintsev, A.G. (1988b) New data on the origin of the Arctic race. In Paleoanthropology and Archaeology in the Western and Southern Siberia (Alekseev, V.P., ed.), Nauka, Novosibirsk, pp. 66-83. (In Russian)

Kozintsev, A.G. (1990) Ainu, Japanese, their ancestors and neighbours: Cranioscopic data. J. Anthrop. 
Soc. Nippon 98, 247-267.

Laughlin, W.S., Jørgensen, J.B., and Frøhlich, B. (1979) Aleuts and Eskimos: Survivors of the Bering Land Bridge coast. In The First Americans: Origins, Affinities, and Adaptations (Laughlin, W.S., and Harper, A.B., ed.), Gustav Fischer, New York, pp. 91-104.

Laughlin, W.S., Okladnikov, A.P., Derevyanko, A.P., Harper, A.B., and Atseev, I.V. (1976) Early Siberians from Lake Baikal and Alaskan population affinities. Am. J. Phys. Anthropol. 45, 651660.

Levin, M.G. (1963) Ethnic Origins of the Peoples of Northeastern Asia. University of Toronto Press, Toronto.

Li, Y., Brace, C.L., Gao, Q., and Tracer, D.P. (1991) Dimensions of face in Asia in the perspective of geography and prehistory. Am. J. Phys. Anthropol. 85, 269-279.

Ossenberg, N.S. (1969) Discontinuous morphological variation in the human cranium. Ph. D. thesis of University of Toronto, Toronto.

Ossenberg, N.S. (1970) The influence of artificial cranial deformation on discontinuous morphological traits. Am. J. Phys. Anthropol. 33, 357-372.

Ossenberg, N.S. (1986) Isolate conservatism and hybridization in the population history of Japan: The evidence of nonmetric cranial traits. In Prehistoric Hunter-Gatherers in Japan (Akazawa, T., and Aikens, C.M., ed.), University of Tokyo Press, Tokyo, pp. 199-215.

Ossenberg, N.S. (1992) Nonmetric traits of the skull help reconstruct prehistory in northwest North America. In Emergence of Modern Humans in the Pacific Region: Proceedings of the CircumPacific Prehistory Conference (Krants, G., and Ho Chuan Kon, ed.), Seattle. (in press)

Rychikov, Yu. G., and Movsesyan, A.A. (1972) A genetical-anthropological analysis on the distribution of cranial anomalies in the Mongoloids of Siberia in connection with the problem of their origin. Transactions of the Moscow Society of Naturalists 43, 114-132. (In Russian with English summary)

Saitou, N., Tokunaga, K., and Omoto, K. (1992) Genetic affinities of human populations. In Monograph SSHB series \#30: Isolation, Migration and Health (Roberts, D.L., Fujiki, N., and Torizawa, K., ed.), Cambridge University Press, Cambridge, pp. 118-129.

Sjøvold, T. (1973) The occurrence of minor non-metrical variants in the skeleton and their quantitative treatment for population comparisons. Homo 24, 204-233.

Sneath, P.H.A., and Sokal, R.R. (1973) Numerical Taxonomy. W.H. Freeman and Company, San Francisco.

Tomashevich, T.V. (1988) Supraorbital canals: Regularities of frequencies distribution. Vopr. Anthropol. 80, 119-128. (In Russian with English summary)

Trofimova, T.A. (1932) On the Ainu question. Anthropological Journal 2, 89-104. (In Russian)

Trubnikova, O.B. (1980) On the classification of the neolithic series from the northern and eastern Asia based on the craniometrical traits (Multivariate statistical method). In Paleoanthropology of Siberia (Okladnikov, A.P., and Alekseev, V.P., ed.), Nauka, Moscow, pp. 89-105. (In Russian)

Turner, C.G., II (1971) Three-rooted mandibular first permanent molars and the question of American Indian origins. Am. J. Phys. Anthropol. 34, 229-242.

Turner, C.G., II (1976) Dental evidence on the origins of the Ainu and Japanese. Science 193, 911 913.

Turner, C.G., II (1983) Dental evidence for the peopling of the Americas. In Early Man in the New World (Shutler, R., Jr., ed.), Sage Publications, Beverly Hills, pp. 147-157.

Turner, C.G., II (1985) The dental search for native American origins. In Out of Asia: Peopling the Americas and the Pacific (Kirk, R., and Szathmary, E., ed.), The Journal of Pacific History, 
Canberra, pp. 31-78.

Turner, C.G., II (1986a) Dentochronological separation estimates for Pacific Rim populations. Science 232, $1140-1142$.

Turner, C.G., II (1986b) The first Americans: The dental evidence. National Geographic Research 2, 37-46.

Turner, C.G., II (1987) Late Pleistocene and Holocene population history of East Asia based on dental variation. Am. J. Phys. Anthropol. 73, 305-321.

Turner, C.G., II (1989) Teeth and prehistory in Asia. Sci. Am. 260(2), 70-77.

Turner, C.G., II (1990) Major features of Sundadonty and Sinodonty, including suggestions about East Asian microevolution, population history, and late Pleistocene relationships with Australian aboriginals. Am. J. Phys. Anthropol. 82, 295-317.

Turner, C.G., II, and Bird, J. (1981) Dentition of Chilean Paleo-Indians and peopling of the Americas. Science 212, 1053-1055.

Yamaguchi, B. (1977) A comparative study of the skulls of the Ontario Iroquoians and of Asiatic populations. Bull. Natn. Sci. Mus., Ser. D (Anthrop.) 3, 23-35.

Yamaguchi, B. (1981) Non-metric variants in the postcranial bones of the Ainu, Iroquois, and Japanese. Bull. Natn. Sci. Mus., Ser. D (Anthrop.) 7, 17-27.

Yamaguchi, B. (1982) A review of the osteological characteristics of the Jomon population in prehistoric Japan. J. Anthrop. Soc. Nippon 90 (Suppl.), 77-90. 